\section{MARCSA Attila}

\section{A VÁLLALATI \\ REPUTÁCIÓS TŐKE MEGÓVÁSA KRÍZIS IDEJÉN}

A vállalatok egyetlen pillanatra sem engedhetik meg maguknak, hogy figyelmen kívül hagyják a tevékenységükkel kapcsolatos, éppen aktuális társadalmi, közösségi elvárásokat: folyamatosan tisztában kell lenniük a legfontosabb csoportok - különösen az alkalmazottak, a befektetốk, a beszálít́́k, az ügyfelek és a helyi közösségek - elvárásaival. Hosszú távon ez kifizetốdik, mivel a pozitív reputáció számtalan elônynyel jár: tekintély az üzleti tárgyalások során és a szerződéskötéskor, alacsonyabb reklámköltség, sikeres szövetségek, nagyobb alkalmazotti lojalitás, nagyobb mozgástér a döntéshozatalban, a botrányokkal és a válságokkal szembeni immunitás. A szerzố írásában az elmúlt harminc év négy híres vállalati krízisét (a Johnson \& Johnson 1982-es Tylenol-visszahívását, a Perrier 1990-es ún. benzolkrízisét, a Pepsi-Cola 1993as esetét az injekciós túkkel és a Bridgestone/Firestone 2000. évi gumiabroncs-visszahívását) elemzi, majd rendszerezve a tanulságokat - rögzíti azokat a legfontosabb alapelveket és teendóket, amelyek segítségével krízis idején is megóvható a vállalati reputációs tóke.

Kulcsszavak: reputációmenedzsment, vállalati kommunikáció, krízismenedzsment, kríziskommunikáció

A vállalatok manapság sokkal inkább számíthatnak morális jellegú vizsgálatra és értékelésre, mint a múl ban. Az üzlet világában ma már magasabbak az elv rások, fontossá vált az üzleti tisztesség is: az emberek már nemcsak jó pénzügyi eredményeket várnak el, hanem azt is igénylik, hogy a vállalatok mindezt a fair play szabályait betartva, társadalmi felelósséget vállalva érjék el. Ha belelapozunk a Financial Times vagy a Fortune valamelyik számába, a kamatlábakról, a piaci trendekról és a vállalatfelvásárlásokról szóló anyagok mellett olyan cikkeket fogunk tó́mi án mellett (éch cikek a vát lalatok (és mizön kulönbözón mán vagy arról szónak, hogy az ûzletí iskolák tanterveibe be kellene építeni az etikát. Az új szabály az üzleti életben azt hirdeti, hogy a profit és a társadalmi felelôsség elválaszthatatlanok. A hosszú távú profit a reputációból származik, amelynek alapja az erkölcsi megkérdójelezhetetlenség és a fair play. Az új paradigmába (Fombrun, 1996; Dowling, 2001; Griffin, 2002; Riel - Fombrun, 2007) kulcsfontosságú a reputációs tóke megléte és folyamatos növelése.

\section{A krízisek jellemzó}

A vállalati kríziseket okozhatja természeti eró, emberi tévedés vagy tudatos károkozás. Az eredmény lehet materiális (halál, egészségkárosodás, vagyoni kár) vagy immateriális (a márka és az imázs károsodása, például egy szervezet szavahihetôségének elvesztése). Bár minden krízis egyedi, vannak közös jellemzók

- a meglepetés eleme (például a Pepsi értesül egy Diet Pepsi dobozban talált injekciós túról),

nem áll rendelkezésre elegendó mennyiségú információ (ennek ellenére szinte azonnal olyan helyzetben találja magát a vállalat, amelyben sokat kell magyarázkodnia),

- az események gyors tempója (nincs idố a tervezésre, a helyzet nagyon hamar kritikussá válhat)

- intenzív figyelem (a média és a közvélemény részéról).

A menedzsereknek leginkább az okoz nehézséget, hogy könnyen elveszíthetik a helyzet feletti uralmukat: a fejük fölött folyamatosan átcsapnak az egymást köve- tő váratlan események hullámai. Ráadásul a médiaôrìlet, amely általában körülveszi a krízist, arra kényszeríl a menedzsereket, hogy rövid távra összpontosítsanak. A figyelem az üzlet egészéról egyedül a krízisre terelődik. Probléma az is, hogy a szervezetek - amíg nem élnek át egy jelentósebb krízist - általában nem értik vagy nem fogadják el, mennyire sebezhetók.

\section{Híres krízisek}

A) A Johnson \& Johnson visszahívja a Tylenolt (1982)

A Johnson \& Johnson (J\&J) Tylenol-visszahívását sokan a kríziskezelés etalonjának tartják. Bár már több mint 25 év telt el az eset óta, a belóle leszúrhetó tanulságok még mindig érvényesek és lényegesek. 1982 szeptemberének végén és októberének elején heten hatak meg, miután kis mennyiségú ciánnal szennyezett Tylenol-kapszulákat vettek be. Akkoriban a Tylenolnak majdnem $40 \%$-os részesedése volt a vény nélkül kapható fájdalomcsillapítók piacán. A mérgezésekrốl szoló elsố közlemény után az értékesítés napokon belư majdnem 90\%-kal csökkent. A Johnson \& Johnson gyors és törődésról árulkodó reakciója volt elsősorba az oka annak, hogy a katasztrófából a vállalat diadala lett. Annak ellenére, hogy a közvetlen veszteség meghaladta a százmillió dollárt, a Tylenol néhány év alatt visszaszerezte korábbi pozícióit.

Mit tett a Johnson \& Johnson? Fontos, hogy nem csupán reagált a történtekre, hanem támadásba lendült, és eltávolíttatta az üzletek polcairól a potenciálisan halálos terméket. Másrészt elhatározta, hogy inkább me menti a márkát (azaz nem ad új identitást a terméknek). Harmadsorban a vállalat gondoskodó módon és emberségesen reagált, és az esetet nem tisztán jogi vagy pénzügyi szempontból nézte. A J\&J-alkalmazotta ezrei egymilliónál több személyes látogatást tettek kórházakban, az orvosoknál és a gyógyszerészeknél országszerte, hoog helyreálítsák a bizalmat a Tyleno iránt (Leavitt - Lipman-Blumen, 1995).

Közismert, hogy a Johnson \& Johnson egyik alapdokumentutua Krédó (egy 308 szavas vállalati tik kódex), méc 1935-ben fogalmatak meg, hogy erősítsék a csapatszellemet: „Hisszük, hogy első́dleges felelôsségünk az orvosokhoz, ápolónókhöz, betegek hez, anyákhoz és mindazokhoz fúz bennünket, akik használják termékeinket és szolgáltatásainkat." 1982 ben a vállalat akkori vezérigazgatójának, James Burkenek gondja volt rá, hogy a Krédó alapelvei vezéreljêk a vállalat cselekedeteit a Tylenol-krízis alatt. Ezzel J\&J úgy tudott reagálni a tragédiára, hogy közbe nem veszítette szem elôl a fontosnak tartott értékeket.
A krízis kirobbanásától számított három hónapon belül vállalat visszaszerezte piaci részesedésének $95 \%$-át. 2001 augusztusában a Business Week és az Interbrand a Johnson \& Johnson márkaportfólióját az első helyre rangsorolta a világon, és a portfólió értékét több, mint 68 milliárd dollárra becsülte. A J\&J napjainkban is a világ „leginkább csodált vállalatai” közé tartozik (Riel - Fombrun, 2007).

\section{B) A Perrier-benzolpánik (1990)}

A Perrier néhány évvel a Tylenol-ügy után élte át saját termékszennyeződési krízisét. Bár ekkor nem for( cet ugón ás és magyarázatra volt szükség a nyilvános-

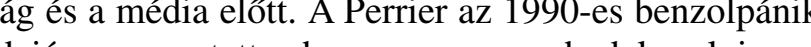
dején megmutatta, hogyan nem szabad kezelni egy rízist (Fombrun, 1996).

1990 februárjában a Perrier a következő sajtóközleményt adta ki:

A Perrier Group of America, Inc. önként visszahív minden Perrier szénsavas ásványvizet (simát és ízesítettet) az Egyesült Államokban. A Food and Drug Administration (FDA, az élelmiszerek és a gyógyszerek forgalomba hozatalát engedélyezó hatóság) és Észak-Karolina állam vizsgálatai a benzolnak a javasolt szövetségi szabványszint fölötti jelenlétét mutatták ki olyan termékekból vett elszigetelt mintákban, amelyeket 1989 júniusa és 1990 januárja között állítottak elō."

Ez a sajtóközlemény a vég kezdetét jelentette. 989-ben a Perrier még egymilliárd palack szénsavas ásványvizet adott el, meglovagolva az 1980-as évek egészségmanniajat. 1990 januárjában azonban egy technikus az észak-karolinai Charlotte városában parányi mennyiségú (kevesebbet, mint amennyit egy csészényi kávé tartalmaz) benzolt fedezett fel a vízben. Két nappal a krízis kirobbanása után (miután 70 millió palackot visszahívtak Észak-Amerikából, de még azelőtt, hogy azonosították volna a szennyezódés forrását), a Perrier America elnöke, Ronald Davis maRonald Davis ma-



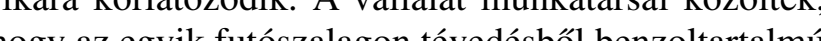
hogy az egyik futószalagon tévedésból benzoltartalmú isztitofolyadékot használtak. A szennyezôdés valód kát (a forrásnál lévó hibás szúrớket) azonban csak három nappal késốbb derítették fel, és kiderült, hogy a botrány a Perrier teljes (globális) piacát érinti. A cég arra kényszerült, hogy megvaltoztassa a "történetet". A Perrier - krízisterv híján - a médiára támaszkodott a történet kommunikálásában, ami végzetes döntésnek bizonyult. A sajtó mindössze a vállalaton belüli 
kommunikáció hiányát tárta fel. Egy párizsi sajtókonferencián, ahol a Perrier-France bejelentette, ók is viszszahívják a terméket a benzol jelenléte miatt, a Perrier egyik menedzsere azzal a magyarázattal állt elö, hogy „a Perrier víz természetes körülmények között is sz mos gázt, közöttük benzolt is, tartalmaz". A sajtóhoz eljuttatott ellentmondásos üzenetekből világossá vált, hogy az amerikai vállalat nem jól kommunikált - mâ ha kommunikált egyáltalán - európai partnereivel. Ráadásul elôkerült egy újabb történet a benzol jelenlétének magyarázatára - és ez is ellentmondott a kolétének magyarázatáa - és ez is ellentmondott a korábbiaknak. A Penier egyik munkatársa szerint „,a be zol a Dél-Franciaországban található vergeze-i forrâs piszkos csôszúroôi miatt került a vízbe". Mindez ártott a
vállalat szavahihetôségének. A Perrier 1989-es - még vállalat szavahihetóségének. A Perrier 1989-es - még a krízis elő́tti - 44,8\%-os piaci részesedése 1998-r 5,1\%-ra zuhant. A Perrier benzolkrízise nemcsak az illusztrálja, hogy milyen következményei vannak kríziskezelésben a kizárólag reaktív stratégiának, hanem azokat a problémákat is, amelyek abból fakadnak, hogy nem volt összehangolt és tényekre alapozott kríziskommunikációs terv.

C) A Pepsi-Cola és az injekciós tü (1993)

A Pepsi-Cola is szembekerült saját, nagy visszhangot kiváltó krízisével, röviddel a Perrier benzolügye után. Az a mód azonban, ahogyan a Pepsi kezelte az 1993-as krízist, éles ellentétben áll a Perrier példájával. Amellett, hogy kifejezte aggodalmát, továbbá bizonyította eltökéltségét, hogy a probléma mélyére hatol, a Pepsi ügyesen állított maga mellé két kritikus fontosságú csoportot (a kormányt és - ami talán még fontosabb - a médiát).

1993 júniusában egy Washington állambeli férfi közölte, hogy miután elózó este megivott egy fél doboz Diet Pepsit, másnap reggel, amikor beleöntötte a maradékot a lefolyóba, injekciós tút fedezett fel a dobozban. Így kezdődött a Pepsi nagy krízise. A Pepsi-Cola North America vezérigazgatója, Craig E. Weatherup nem esett kétségbe, amikor az FDA vezetóje, David Kessler est helyzetról. Elsó do otthonában, és informálta Pepsi-Cola négytagú kríziskezelô csoportját, amely taAz volt a feladatuk, hogy gyorsan kezeljék a kibontaAz volt a feladatuk, hogy gyorsan kezeljék a kibonta-
kozó krízist, aminek része volt az is, hogy kommunikákozó krízist, aminek része volt az is, hogy kommunikációs vonalakat építettek ki az FDA tisztségviselóivel, a médiával és a fogyasztókkal. A vállalaton belül a Pep azzal elôzte meg a szervezeti káoszt, hogy naponta friss információkat küldott az országszerte több mint 400 telephelyen dolgozó alkalmazottainak. Szemben a Johnson \& Johnsonnal, amely haladéktalanul visz- szahívta a Tylenolt, másnap reggelre Weatherup úgy döntött, hogy nem hívja vissza a terméket - annak ellenere, hogy addigra az FDA már több bejelentest is kapott olyan Pepsi-dobozokról, amelyekben injekciós tút találtak.

Amikor a televíziós hálózatok kapcsolatba léptek a vállalattal, hogy valamilyen hivatalos nyilatkozatot kapjanak, Weatherup rádöbbent, hogy a krízis gyökere a dobozban talált injekciós tú képe, és elhatározta, hogy a vállalat ,vizuális választ” ad a kérdésekre. Weatherup munkatársaival videofelvétel-sorozato Wészíttetett a Pepsi doboztöltő futószalagiáról, amely hogy gyakorlatilag lehetetlen injekciós tút nni a dobozokba. A Pepsi késóbb eljuttatott a nagy levíziós társaságokhoz egy élelmiszerbolti kamera altal rögzített képsort egy nớról, aki lopva injekciós tút jt Pepsi-dobozába. Miután a képsor három híradóban is megjelent, megszúntek az injekciós túkroól szóló új jelentések. Weatherup maga is több alkalommal megjelent a televízióban, egyik alkalommal elkísérte David Kessler, az FDA vezetóje is. Mindketten hangsúlyozták az állítások valószínútlenségét és azt, hogy a hamis állítások (5 éves börtönbüntetéssel és akár 250000 dolláros pénzbírsággal sújtható) búncselekménynek minősülnek A Pepsi rájött, hogy az FDA felbecsülhe(a) látványos egyuit látványos egyû́ttmúkoỏdése a hatớságokkal növelte szavahihetơségét a közvélemény szemében). Végül $20 \mathrm{em}-$ bert tartótatak le a hamis állítások miatt, és a krízis megoldódott. A Pepsi-Cola azonban nem állt meg itt. Biztosítandó, hogy a fogyasztók tudják, a termékmanipulálásról szóló állítások hamisak, a cég hirdetéseket jelentetett meg 200 újságban, hogy az alkalmazottak és a vevók aggodalmait eloszlassa. A hirdetés így szólt: „A Pepsi örömmel közli, hogy... nem történt semmi. Mint most már egész Amerika tudja, a Diet Pepsiról szóló történetek kacsák voltak. Egyszerúen nem voltak igazak.” A hirdetés a következóképpen zárult: „Igyanak annyi Pepsit, amennyi csak magukba fér! Ugy bizony!" A Pepsi a világ egyik vezetố üdítóital-gyártója ma is, ami azt bizonyítja, hogy a krízishelyzar toja ma is, ami azt bizonyítja, hogy a krízishelyzetek
leküzdhetốk.

D) A Bridgestone/Firestone gumiabroncs-visszahívása (2000)

A félrekezelt vállalati krízisek tartós kárt okozhatnak még a nagyra becsült márkáknak is, amint ezt a Bridgestone/Firestone 2000. évi gumiabroncs-visszahívása tanúsítja. Harvey S. Firestone 1900-ban alapította a Firestone Tire and Rubber Companyt. Amikor Henry Ford megkereste a Firestone-t, és megkérte, adjon el gumiabroncsokat a Ford autókhoz, megszü- letett az amerikai ipar történetének egyik leghosszabb ideig tartó üzleti partnersége. A történelmi kötelékek ellenére a 2000. év a Ford-Firestone-kapcsolat széthulásának éve lett. Ennek oka az a sok száz baleset volt, ami azért következett be, mert a Firestone-futófelületek leváltak a Ford Explorerekról. Mivel mindkét vállala attól rettegett, hogy irtózatos veszteségei lesznek, ha egyedül vállalja a teljes felelősséget a balesetekért, megvolt bennük az indíték, hogy az eseményekért másikat hibáztassák. A Ford azt állította, hogy a probléma a Firestone abroncsszériája, míg John Lampe, Bridgestone/Firestone vezérigazgatója John Lampe, Bridgestone/Firestone vezérigazgatója ",a Ford Exp-
lorerekkel kapcsolatos biztonsági aggodalmakról" beszélt. Szerinte ezen a típuson ötször több leválásró számoltak be, mint a Ford Rangernél, amelyen ugyanaz számoltak be, mint a Ford

Firestone-abroncs volt.

E nagy nyilvánosságot kapott krízis eredményeként a Firestone a Fortune magazin 2001. évi listájân az utolsók közé zuhant a „leginkább csodált vállalatok" között. Bár az ujjal mutogatás rossz fényt vetett mind a Fordra, mind a Firestone-ra, különösen a Firestone imázsának és reputációjának ártott a krízis. Vajon a krízis mely elemeit kezelte rosszul Firestone? Először is a fogyasztók elvesztették bizalmukat a Firestone-ban a tragédiákra adott késedemes vállalati reakció miatt, amely - érzéseik szzint mes vállarti A Firestone kezdetben az a szahívását javasolta - ennek oka egyébként az volt, hogy nem tudták egyszerre legyártani a szükséges hogy nem tudták egyszerre legyártani a szükséges
pótlásokat - , de ez felbőszítette a vásárlókat azokpótlásokat - , de ez felbôszítette a vásárlókat azokban az államokban, amelyek nem kerültek be az elsố szakaszba, és közülük sokan csoportos pert indítottak a vállalat ellen. A Firestone azzal is próbálkozott, hogy az abroncshibákat a rossz keréknyomásnak és karbantartásnak tulajdonítsa, tehát - legalábbis részben - magukat az autótulajdonosokat okolta a balesetekért. Egyre inkább úgy túnt, hogy a vállalat megpróbál kibújni a felelôsség alól, és csak a saját üzleti érdekeit próbálja védelmezni.

Amikor a Firestone végül proaktív stratégiáva állt elő a krízis kezelésére, az is az autókereskedóket célozta meg, nem az autótulajdonosokat - tehát nem azokat, akiket a legközvetlenebbül érintettek a tragikus balesetek. Mivel a gumiabroncsiparban a gyártók távol vannak a vevớktő́l, a Firestone a helyi autókereskedókkel közösen jelentetett meg hirdetéseket. A vállalat megpróbálta semleges harmadik félkén felhasználni az autókereskedôket saját márkájána újrafelépítésére. Csak 2001 februárjában, majdnem hét hónappal a visszahívás után, kezdett a Firestone közvetlenül a fogyasztókhoz szólni. A vállalat elin- dította a TireSafety.com-ot, amely fontos informácikkal szolgált a napi abroncskarbantartásról, miközben kiemelt helyen szerepeltette a Firestone nevet. Mivel a vállalat a nem megfeleló keréknyomást a Ford Explorer-balesetek lehetséges okaként jelölte meg, a honlapon ingyenes abroncsmérést ajánlott fel a feliratkozóknak, valamint azt, hogy kérésre e-mail figyelmeztetést küld a vásárlóknak arról, hogy mikor kell ellenốrizni az abroncsnyomást a biztonság érdekében (Frank, 2001). Azzal azonban, hogy elôször rossz irányba indult el, a Firestone azt a látszatot keltette hogy csak akkor figyel a fogyasztók bizto kel gára amikor sarokba szorítík és nem aźit, mert ez része a vállatat filozofíjénak. Ha állatat gyo és határozottan cselekedett volna, vállalva a feleorsós et a szerencétenśgekért, a fogya tebbnek érezték volna magukat, és tó negbecsullettek vo eatek volna magukat, es talán hajlandóak letck volna megbocsátani a vállalatnak. A Firestone esete igazolja, hogy még tiszteletre méltó régi márkák is milyen gyorsan és drámaian válhatnak kegyvesztetté, ha rossz a kríziskommunikációjuk. A Ford reputációját is megtépázta a krízis, de a kommunikációs szakemberek és a fogyasztók is úgy érezték, hogy a két vállalat közül a Ford reagálása gyorsabb és empatikusabb volt.

Érdemes összefoglalni az elóbbiekben ismertetett négy eset tanulságait. A továbbiakban két lényeges kérdést vizsgálunk meg:

Hogyan készüljünk fel a krízisre?

- Mik a legfontosabb teendók krízis idején?

\section{Felkészülés a krízisre}

Az elsố lépés a krízisre való felkészuilés során annak megértése, hogy egy vállalat bármikor (egyik pillanatról a másikra) krízishelyzetbe kerülhet. Nyilvánvaló, hogy bizonyos iparágakban (például a vegyiparban, a gyógyszeriparban, a bányászatban, az erdészetben, a gáz- és az áramszolgáltatók körében) gyakoribbak a krízisek, ma már azonban minden iparág és minden vállalat veszélyben van. A vállalatoknak érdemes krízistervet készíteniük, amelynek mindenképpen tartalmaznia kell a következő elemeket: krízis esetén értesítendốk listája, sajtólista, az alkalmazottak értesítésének módja, a krízisközpont helye. A vállalatoknak érdemes írásban dokumentálniuk krízistervüket. A kommunikációs stratégián kívül a krízistervnek foglalkoznia kell logisztikai részletekkel is (például azzal, hol helyezzék el az áldozatok családtagjait légi baleset esetén). Egy átfogó terv kidolgozását követően minden menedzsernek meg kell tanulnia (például egy tréning keretében), hogy mi a teendố krízishelyzetben. 
A legfontosabb teendók krízis idején a vállalati reputációs tốke megóvása érdekében

1. Kézben kell tartani a helyzetet!

Először is tisztázni kell, hogy mi történt/történik, és lehetôleg azt is, hogy mi okozta/okozza a problémát. Ha ezt a döntố jelentôségú lépést a vállalat nem tesz meg, az végzetes lehet a későbbiekre nézve, amint ezt Perrier esetében láthattuk.

2. Össze kell gyüjteni a lehetö legtöbb információt! $\mathrm{Az}$ adott probléma megértése után a menedzserek Az adott probléna megentuse után a menedzserek elkezdhetnek a krízissel foglalkozni. Sok vállalatot bí-
ráltak már azért, mert túl lassan reagált krízis idején, ráltak már azért, mert túl lassan reagált krízis idején, mivel kétségbeesetten igyekezett információt gyújteni formáció összegyúitése néhány óránál több idő́t vesz formáció összegyújtése néhány óránál több idốt vesz
igénybe, a vállalat szóvivớjének ezt azonnal közölnie kell a médiával és más kulcsfontosságú csoportokkal, hogy világos legyen: a vállalat nem obstruál. Senki sem bírál egy szervezetet azért, mert megpróbál rájönni, mi is történik. Ellenben kíméletlen bánásmódra számíthat, ha az érdekelt csoportok úgy vélik, hogy a menedzsment tudatosan gátolja az információáramlást.

\section{Centralizált kríziskezeló központ felállítása}

Az elsố két lépéssel párhuzamosan fel kell állítan egy kríziskezelő (és egyben kommunikációs) központot. A lehetőségekhez mérten kényelmes munkafeltételeket kell biztosítani az újságíróknak és a riportereknek. Soha ne feledkezzünk meg arról, hogy a krízis sorá mindvégig szükségünk lesz a média jóindulatára!

\section{Korai és gyakori kommunikáció}

A szervezet szóvivőjének a lehetó leghamarabb e kell mondania, amit csak tud. Az alkalmazottaknak, a médiának és más fontos csoportoknak tudniuk kell hogy - ellenkezó tartalmú értesítésig - a krízisközpon rendszeres idóközönként frissített információval szogál majd. A Firestone példája bizonyítja, hogy mennyire káros lehet a megkésett kommunikáció. Kommuiká junkértékeket (i)

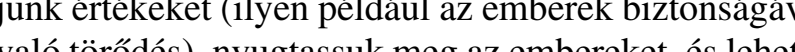
leg kerüljük el a pánikot!

\section{Meg kell érteni a média küldetését!}

Az újságírók és a riporterek rendkívül erôs versenyben dolgoznak, egyszersmind hozzá vannak szokva krízisekhez. Amit keresnek, az a jó sztori - áldozatokkal, negatív figurákkal és vizuálisan megjeleníthetô részletekkel. A Pepsi megértette, hogy a vizuális elemek nagy hatást gyakorolnak a kôzveleményre, es se- gítségükkel bizonyította, hogy a termékmanipulálásra vonatkozó állítások egyszerúen lehetetlenek. A Peps töltési eljárását bemutató képsorok és az élelmiszerbolti videoszalag, amelyeket a televízióban bemutattak, valamint az egész oldalas újsághirdetés - mind példák arra, hogyan használta fel a Pepsi a médiát a krízis leküzdésére.

\section{Közvetlenül az érintettekkel kell}

kommunikálni

Érdemes a médiát használni arra, hogy információt hozzunk nyilvánosságra, de még ennél is fontosabb, hogy az alkalmazottakkal (az értékesítésben dolgozókkal, a biztonságiakkal, a telefonközpontosokkal, a recepciósokkal stb.) kommunikáljunk, mivel krízis idején többnyire ốk a média információforrásai. A kulcsfontosságú külsố csoportokkal (a vevốkkel, a részvényesekkel, a közvetlenül érintett helyi közösséggel, a mentôsökkel, a túzoltókkal, a rendôrökkel, az érintett hatóságok tisztségviselóivel stb.) is kapcsolatba kell lépni. A kommunikáció elótt a vállalatnak azt is át kell gondolnia, hogy az érintettek mely csoportja a legfontosabb. A Firestone egyik fố tévedése éppen az volt, hogy első körben a kereskedóket vette célba ahelyett, hogy egyenesen a vásárlókhoz (a legközvetlenebbiil érintettekhez) szólt volna.

\section{Az üzlet nem állhat le!}

A menedzsereknek végig kell gondolniuk, hogyan hat a krízis az üzleti tevékenység más részeire. Le kell-e állítani valamelyik hirdetési kampányt a krízis idejére? Folytatható-e a kereskedés a vállalat részvényeivel? A dolgozóknak (vagy egy részüknek) a krízis idótartamára ideiglenesen el kell-e költözniük? Mindezeket és a folyamatos üzletmenettel kapcsolatos egyéb kérdéseket a lehetô leghamarabb át kell gondolniuk a menedzsereknek.

\section{Haladéktalanul tervet kell készíteni az újabb}

\section{krízis elkerülésére!}

Azok a vállalatok, amelyek már átéltek egy krízist, jobban elhiszik, hogy az efféle események ismét megtörténhetnek, és azt is felismerik, hogy a felkészülés a sikeres kríziskezelés kulcsa. A Johnson \& Johnson 1982-es tapasztalatai például segítettek a társaságnak megbirkózni egy újabb termékszennyezódéses esettel, négy évvel késő́bb, amikor egy New York-i lakos halt meg, miután csekély mennyiségú ciánnal szennyezet Tylenol-kapszulákat vett be. Nincs megfelelốbb idôszak, mint a krízist közvetlenül követố periódus, hogy feldolgozzuk a tapasztalatokat és tanuljunk az elkövetett hibákból.

\section{Felhasznált irodalom}

Dowling, G. (2001): Creating Corporate Reputations. Oxford: Oxford University Pres

Fombrun, C.J. (1996): Reputation: Realizing Value from he Corporate Image. Boston: Hawa Business School Press

Fifety push goes online. $P R$ Week, február 19., 8. o.
Griffin, G. (2002): Reputation Management. Oxford: Capston

Leavitt, H.J. - Lipman-Blumen, J. (1995): Hot Groups. Harvard Business Review, július-augusztus, 109-116. o.

, Cees B.M. van - Fombrun, C. J. (2007): Essentials Routledge Sonnenfeld, S. (1994): Media Policy - What Media Policy? Harvard Business Review, július-augusztus, 18-26. o.

\section{E SZÁ MUNK SZERZÖI}

Dr. Kövesi János, egyetemi tanár, tanszékvezető, dékán, Budapesti Múszaki és Gazdaságtudományi Egyetem, Menedzsment és Vállalatgazdaságtan Tanszék, kovesi@ @ mvt.bme.hu; Petruska Ildikó, egyetemi docens, Budapesti Múszaki és Gazdaságtudományi Egyetem, Menedzsment és Vállalatgazdaságtan Tanszék, petruskai@ @ mvt.bme.hu; Szilvia Bíró-Szzigeti, assistant lecturer, Department of Management and Corporate Economics, Budapest University of Technology and Economics, $\mathrm{Bu}-$ dapest, Hangar, szigetis_@ Economics, Budapest Universty of Technology and Economics, Budapest, Hungary, vagasim@ mvt.bme.hu; Dr. Vasné Egri Magdolna, egyetemi docens, Budapesti Múszaki és Gazdaságtudományi Egyetem, Menedzsment és Vállalatgazdaságtan Tanszek, egnnenter ment és Vallatgazdaságtan Tanszék, kovass.istvan @ mvt.bme.hu; Jonás Tamás, múkỏdés-hatékonysági vezetố, Flextronics International Kn., PhD-hallgató, Bucapesti Muszaki és Gazdaságtudományi Egyetem, Menedzsment es Vallalatatgazdaságtan


dományi Egyetem, Menedzsment es Vallalatgazdaságtan Tanszek, tothzs@mvt.bme.hu, Marssa Attila, tudományos segédmunkatârs, Budapesti Múszaki ês Gazdaságtudományi Egyetem, Menedzsment és Vállalatgazdaságtan Tanszék, marcsa@ mvt.bme.hu, Dr. Gyokér Iren, egyetemi docens, Budapesti MALzzaki és Gazdasăgtudomanyi Egyetem, Menedzsment és Vallalatgazdasagtan Tanszek, gyoker @nv.bme.hu; Dr. Finna Henrietta, egyetemi adjunktus, Budapesti Múszzaki és Gazdaságtudomânyi Egyetem, Menedzsment és Vallalatgazdaságtan Tanszék, finnah@ mvt.bme.hu; Dr. Velencei Jolán, egyetemi adjunktus, Budapesti Matszaki es Gazdaságtudományi Egyetem, Menedzsment és Vallalatgazdasăgi Tanszêk, velencei@ mvt.bme.hu, Dr. Szabo Tibor, egyetemi adjunktus, Budapesti Múszaki és Gazdasagtudományi Egyetem, Menedzsment és Vallalatgazdasági Tanszeke, tiborszabo @ mail.bme.hu; Dr. Pataki Béla, egyetemi docens, Budapesti Múszaki és Gazdaságtudományi Egyetem, Menedzsment es Vallalatgazdasagtan Tanszek, pataki@mvt.bme.hu; Dr. Szalkai Zsuzsanna, egyetemi docens, Budapesti Muszaki és Gazdaságtudományi Egyetem, Menedzsment és Vallalatgazdaságtan Tanszék, szalkaizs@ mvt.bme.hu; Bîro-Szigeti Szilvia, egyetemi tanársegéd, Budapesti Múszaki es Gazdaságtudomannyi Egyetem, Menedzsment és Vallalatgazdasaglan Tansžk, szigetisz@ mv.bme.hu, Krajesák Zoltán, gyakonnok tanárseged, Budapesti Múszaki és Gazdaságtudomanyi Egyetem, Menedzsment es Vallalatgazdasagtan Tanszék, krajcsak@mvt.bme.hu; Kelemen Tamás, egyetemi tanársegéd, Budapesti Múszaki és Gazdaságtudományi Egyetem, Menedzsment és Vállalatgazdaságtan Tanszék, kelemen@mvt.bme.hu; Dr. Koltai Tamás, egyetemi tanár, Budapesti Múszaki és Gazdasaggtudományi Egyetem, Menedzsment és Vallalatgazdasagtan Tanszek, koltai@mv.bme.hu, Dr. Romhányi Gábor, egyetemi adjunktus, Budapesti Múszaki és Gazdasăgtadományi Egyetem, Menedzsment és Vallalatgazdaságtan Tanszek, romhanyi@mu.bme.hu; Tatay Viola, PhD-hallgató, Budapesti Mutszaki és Gazdaságtudományi Egyetem, Menedzsment és Vallalatgazdaságtan Tanszêk, tatay@ mvt.bme.hu; Dr. Sebestyén Zoltán, egyetemi docens, Budapesti Múszaki és Gazdaságtudományi Egyetem, Menedzsment és Vállalatgazdaságtan Tanszék, sebestyen@mvt.bme.hu; Kalló Noémi, egyetemi tanársegéd, Budapesti Múszaki és Gazdaságtudományi Egyetem, Menedzsment és Vallalatgazdaságtan Tanszék, kallo@ mvt.bme.hu; Dr. Topár József, egyetemi adjunktus, Budapesti Múszaki és Gazdaságtudományi Egyetem Menedzsment és Vállalatgazdaságtan Tanszék, topar@mvt. bme.hu, Dr. Berces Roland, egyetemi adjunkus, Budapesti Múszaki és Gazdasagtudományi Egyetem, Menedzsment és Vallalatgazdaságtan Tanszék, rberces@mvt.bme.hu; Erdei János, egyetemi adjunktus, Budapesti Múszaki és Gazdaságtudományi Egyetem, Menedzsment és Vallalatgazdaságtan Tanszék, erdei@ mvt.bme.hu; Dr. Szabo Gábor Csaba, egyetemi docens, Budapesti Múszaki és Gazdaságtudomanyi Egyeten, Menedzsmen és Vallalagazdaságlan Tanszek, szabog@mvt. bme.hu; Nagy Jenő Bence, tudományos segédmunkatárs, Budapesti Múszaki és Gazdaságtudományi Egyetem, Menedzsment és Vállalatgazdaságtan Tanszék, nagyj@mvt.bme.hu 